\section{A. Morey \\ C. Lima \\ C. Rapado \\ G.P. Losada \\ J.E. Marco}

Service of Nephrology, CAPD Unit, Son

Dureta Hospital, Palma de Mallorca, Spain

\section{Dear Sir,}

For the past 15 years, the appropriate treatment of end stage renal failure has included both continuous ambulatory peritoneal dialysis (CAPD) and haemodialysis. In some circumstances CAPD has been indicated as a more adequate option. However, the main handicap for CAPD patients is peritoneal infection [1], ranking as the main cause of hospital admission and transfer to haemodialysis [2]. Peritonitis represents the third highest cause of death in CAPD patients [3]. It also produces a $15-19 \%$ deterioration of peritoneal membrane function.

Fighting against peritoneal infection has been a constant challenge for CAPD teams

\title{
Peritonitis per Patient and Year: A Basic Index
}

from the very beginning. It has included the utilization of specially designed connection devices (connectors), integrated systems, routine use of antiseptics, flush before fill procedures and other preventive measures. The number of peritonitis episodes per patient per year $(\mathrm{P} / \mathrm{p} / \mathrm{y})$ is a valid and simple measurement to judge the quality of care provided by CAPD units. It has been surveyed for many years at most CAPD units.

In 1992, our team initiated a new program with two points of emphasis. (1) More involvement of the patients. The inclusion of CAPD patients was strictly voluntary. Hygiene and dietetic habits were reinforced and accepted by the patients. Nutritional status was carefully maintained, as it plays a key role in the incidence of infections [4-6]. Training was methodical and progressive including video and audio recordings [7] and use of other learning material. Patient techniques were reevaluated every 4-6 months. The home conditions included a washing place (or toilet) integrated in (or close to) the exchange room. (2) New strategies adapted by the staff. This included the maintenance of the same medical and nursing team, the homogenization of criteria and protocols, the rapid detection of intercurrent diseases and a close review of the adequacy of dialysis

Fig. 1. Improvement of $\mathrm{P} / \mathrm{p} / \mathrm{y}$ index. $n$ represents number of patients.

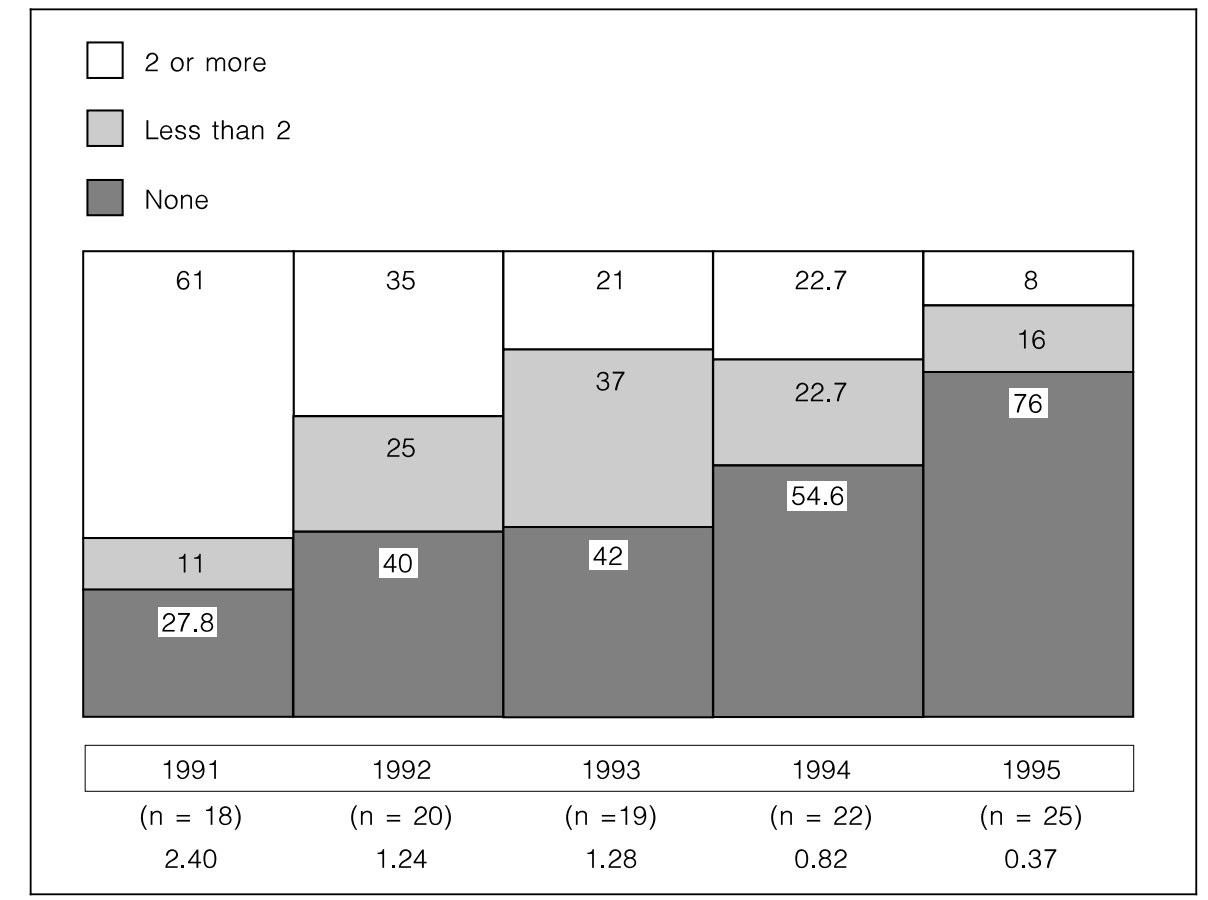

\section{KARGER}

Fax + 41613061234 E-Mail karger@karger.ch www.karger.com

\section{(c) 1998 S. Karger AG, Basel \\ 0028-2766/98/0781-0123\$15.00/0}

This article is also accessible online at: http://BioMedNet.com/karger
Dr. A. Morey

Servicio de Nefrología

Andrea Doria 55

E-07014 Palma de Mallorca (Spain) 
[8]. Furthermore, it included better knowledge and permanent update regarding antibiotics, catheter insertions, accidental disconnections, leaks and breaks and care of the exit site. Fibrinolytic agents were employed in the case of suspected biofilm conditions. Carriers of Staphylococcus aureus (nasal) among personnel and patients, acting together in a dynamic way to prevent depressive situations and other disturbances that may lead to the neglect of a good hygienic practice.

Team effort contributed to a marked decrease in the $\mathrm{P} / \mathrm{p} / \mathrm{y}$ index [9-11] (fig. 1). We conclude that the cooperation of patients and staff is a key factor for decreasing peritonitis. In this setting the professional relationships between physicians and nurses are essential. It is about: 'The need of mutual and reciprocal respect among physicians and nurses' as Mrs Barbara W. Prowant pointed out at the 1st National Meeting of CAPD, Valencia, Spain.

\section{References}

1 Read RR, Eberwein P, Daugupta MK, Grant SK, Kan L, Nikel C, Costerton JW: Peritonitis in peritoneal dialysis: Bacterial colonization by biofilm spread along the catheter surface. Kidney Int 1989;35:614-621.

2 Maiorca R, Cancarini GC, Brunori G, Camerini C, Manili L: Morbidity and mortality of CAPD and hemodialysis. Kidney Int 1993;43: S4-S15.

3 Saade M, Joglar F: Chronic peritoneal dialysis: Seven-year experience in a large Hispanic program. Perit Dial Int 1995; 15:37-41.

4 Heimbürger O, Bergström J, Lindholm B: Maintenance of optimal nutrition in CAPD. Kidney Int 1994;46:S39-S46.

5 Jurado JL, Montoya SF, Cole SK: Hypoalbuminemia in CAPD patients. Perit Dial Int 1995;15:S42.

6 Young GA, Young JB, Young SM, Hobson SM, Hildreth B, Brownjohn AM, Parson FM: Nutrition and delayed hypersensitivity during continuous ambulatory peritoneal dialysis in relation to peritonitis. Nephron 1986;43:177186.
7 Morey A, Rapado C, Lima C, Gacias M, Alarcón A, Gascó J, Serrano P, Bestard J: Original didactic experience in CAPD. Perit Dial Int 1995; 15:S58.

8 Lamier NH, Vanholder R, Veyt D, Lambert MC, Ringoir S: A longitudinal, five year survey of urea kinetic parameters in CAPD patients. Kidney Int 1992:42:426-432.

9 Rotellar C, Black J, Winchester F, Glasp FRCP, Rakowski TA, Mosher WF, Mazzoni MJ, Amiranzavi M, Garagusi V, Alijani M, Argy WP: Ten years experience with continuous ambulatory peritoneal dialysis. Am J Kidney Dis 1991;17:158-164.

10 Domrongkitchaiporn S, Karim M, Watson L, Moriarty M: The influence of continuous ambulatory peritoneal dialysis connection technique on peritonitis rate and technique survival. Am J Kidney Dis 1994;24:50-58.

11 Lupo A, Tarchini R, Cancarini G, Catizonel L, Cocchi R, De Vecchi A, Salomone M, Segoloni $\mathrm{G}$, Giangrande A: Long-term outcome in continuous ambulatory peritoneal dialysis: A 10year survey by Italian Cooperative peritoneal Dialysis Study Group. Am J Kidney Dis 1994; 24:826-837.

\section{Erratum}

In the Editorial Review by Prof. Dr. H.J. Kramer (Nephron 1997;77:1-12) an error occurred in which, on page 9, left column, line 4, reference citations 28 and 37, and line 9, reference citations 38 and 39 should have been deleted, but were erroneously printed. 